\title{
Hepato-protective Effects of Crude Phenol and Petroleum Spirit Root Extracts of Calotropis procera (Sodom of Apple) on CCL4 Induced Hepatotoxicity in Albino Rats
}

\author{
Zaharaddeen Shehu ${ }^{1}$, Garba Uba ${ }^{1}$, A.J. Alhassan $^{2}$ and Muntari Bala ${ }^{2}$ \\ ${ }^{1}$ Department of Science Laboratory Technology, College of Science and Technology, \\ Jigawa State Polytechnic, Dutse. Nigeria \\ ${ }^{2}$ Department of Biochemistry, Faculty of Basic Medical Science, Bayero University, \\ PMB 3011 Kano-Nigeria \\ *Corresponding author
}

\section{Keywords}

Hepatotoxicity, hepatoprotective, livolin, hepatocytes, Calotropis Procera

Article Info

Accepted:

20 January 2019

Available Online:

10 February 2019

\section{A B S T R A C T}

The efficiency of current synthetic agents in treating chronic liver disease is not satisfactory and they have undesirable side effects. The effects of crude phenol root extracts of Calotropis procera, petroleum spirit root extracts of Calotropis procera (PRECP, PSRECP) and livolin on liver function indices of ccl4 induced hepatotoxicity rats model was evaluated. Fifty (50) albino rats were grouped into Five (I, II, III, IV and V) of 10 rats each, $120 \mathrm{mg} / \mathrm{kg}$ body weight ccl4 diluted with olive oil in the ratio 1:1 was administered to rats in groups II, III, IV and V intramuscularly followed by oral administration of $10 \mathrm{mg} / \mathrm{kg}$ livolin, $10 \mathrm{mg} / \mathrm{kg}$, crude phenol and petroleum spirit root extracts of $C$. Procera to group III, IV and V respectively. Groups I and II serves as positive and test control respectively. Analysis of variance (ANOVA) for multiple comparison test were used to compare the indices of the liver and kidney functions for the test and control group at 10 days interval for 20 days. The hepatic biochemical markers Alanine Amino Transferase (ALT), Aspartate Amino Transferase (AST), Alkaline Phosphatases (ALP) of group Gp II were significantly higher $(\mathrm{P}<0.001)$ compared to gpi, while group III (treated with livolin) was statistically decreased $(\mathrm{P}<0.05)$ when compared with control (Gp I), this confirms the toxicity and treatment with livolin respectively. Oral administrations of the PRECP lowered all the liver function markers and increased the concentration of urea and albumin after 20 days of exposure. This indicates that PRECP may reverse the chemically induced tissue damage; in contrast, PSRECP produced toxicity at both exposures as evidenced from the histopathology of the liver hepatocytes. The histopathological analysis of PERCP indicates improved fine architecture of the liver and kidney cells which are comparable to livolin treated group. In conclusion, the overall results suggest that ethanol root extracts of $C$. Procera may have moderate hepatocurative effects when compared to methanol extracts. 


\section{Introduction}

Liver is the very important part of our body responsible for the maximum metabolic and secretary activities and therefore appears to be a sensitive target site for substances modulating biotransformation. Liver is also associated in detoxification from the exogenous and endogenous challenges like xenobiotics, drugs, viral infections and chronic alcoholism. The period and intensity of the pharmacological response to drugs is influenced by their metabolic rate and hence substances capable to modify drug metabolism would be able to change the result of drug therapy. During all such exposures to the above mentioned challenges, if the usual defensive mechanisms of the liver are overpowered, the effect is liver damage. Liver injury or liver dysfunction is a major health problem that challenges not only medical professionals but also the pharmaceutical company and drug regulatory authorities. Liver cell injury caused by various toxic chemicals like certain antibiotics, chemotherapeutic agents, carbon tetrachloride, thioacetamide, excessive alcohol consumption and microbes. Herbal medicines have been applied for the treatment of liver disorder for a lengthy period (Dhiman and Chawla, 2005; Ming et al., 2015).

The use of Traditional medicine in developed as well as developing countries as basis for the treatment of many ailments has been in existence for thousands of years and there is no doubt that their importance has been widely acknowledged. Medicinal plants have continued to play vital roles in the Nigerian healthcare sector, although traditional medical practitioners have not been fully recognized (Emmanuel et al., 2015).

The search for hepatocurative agents that may cure and manage the conditions with high potency dates back to millennia. Various substances of animal and plant origin have been used in folk medicine of different cultures as hepatocurative remedies, some of which have been identified pharmacologically to exert their effects either on the hepatocytes or renal tissues or both (Uba et al., 2017)

Furthermore, ancient literature alluded to the use of numerous plants/preparations including $C$. procera root to treat many diseases including liver and kidney damages without any scientific evidence. To understand the scientific reasons behind these folk claims, this work investigated the effects of organic solvent (phenol and petroleum) extract of $C$. procera root in this study.

\section{Materials and Methods}

\section{Plant materials}

Root of C. procera was collected from Dutse, Dutse local government, of Jigawa State. Specimens of the leaves and bark were removed. The root was dug using hoe and a shovel. The root of Calotropis procera was allowed to dry under the shade, it was then ground using mortar and pestle. The extract of the plant root was prepared by weighing $200 \mathrm{~g}$ and soaking of the root powder in phenol and petroleum spirit solvents separately (BDH) for 2 weeks.

\section{Acute toxicity test in albino rats}

Acute toxicity tests of phenol and petroleum spirit extract of $C$. procera roots were performed separately in male and female rats according to OECD guideline for chemicals tests (OECD, 2001). The limit test at dose level of $2000 \mathrm{mg} / \mathrm{kg}$ body weight was administered orally (gavage) to six fasted males and females albino rats per extract. The females were nulliparous and non-pregnant. The rats of different groups were individually observed for 120 min post-treatment and at 
least once daily for 14 days for mortality and signs of toxicity such as changes in skin and fur, eyes, mucus membranes, convulsion, salivation, diarrhea, lethargy, sleep and coma.

\section{Experimental animals}

Based on Lethal Dose 50 (LD50) values obtained from acute toxicity studies, the selection of dose for sub-chronic toxicity was carried out. The dose selected in this study is $10 \mathrm{mg} / \mathrm{kg}$ body weight. This dose corresponded at 1/100 of LD50 obtained in the acute toxicity tests. Fifty (50) male and female albino rats obtained from the physiology Department, Faculty of Basic Medical Science, Bayero University, Kano, were kept in the departments of Science Laboratory Technology, Jigawa State Polytechnic, Dutse for two weeks acclimatization. The animals were grouped into five (I, II, III, IV and V) of 10 animals each. Group II, III, IV and V were administered with $120 \mathrm{mg} / \mathrm{kg} \mathrm{ccl} 4,10 \mathrm{mg} / \mathrm{kg}$ livolin (a standard antihepatotoxic drug) and $10 \mathrm{mg} / \mathrm{kg}$ PHENOL AND PETROLEUM SPIRIT root extract of $C$. procera respectively; while group I and II serve as control. Group III - V were managed as in the design protocol below; Carbon tetra Chloride $\left(\mathrm{ccl}_{4}\right)$ was dissolved in olive oil and $120 \mathrm{mg} / \mathrm{kg}$ body weight was injected intramuscularly.

Protocols for evaluating hepatocurative activity of $C$. procera root prepared in subsection

Group I: Normal control received neither $\mathrm{ccl}_{4}$ nor extract.

Group II: Negative control, induced with $120 \mathrm{mg} / \mathrm{Kg}$ body weight $\left(\mathrm{ccl}_{4}\right)$, no extract.

Group III: Hepato-induced toxicity rats Administered with10mg/kg Livolin.

Group IV: Hepato-induced toxicity rats administered with $13 \mathrm{mg} / \mathrm{kg}$ PHENOL extract.

Group V: Hepato-induced toxicity rats administered with $10 \mathrm{mg} / \mathrm{kg}$ PETROLEUM SPIRIT extract.

\section{Biochemical assay}

The liver function indices (AST, ALP, ALT, bil., ALB) were carried out according to the procedure explained by Clementine and Tar Choon, (2010), while the kidney function test and electrolytes were carried out according to the procedure of Gowder et al., (2010)

\section{Histopathology}

The biopsies of the liver were fixed with $10 \%$ formal saline, dehydrated with ascending grade of alcohol, cleared with toluene, infiltrated with molten paraffin wax. Section of the liver was stained with haematoxylin and Eosin method (Ovwioro, 2002).

\section{Statistical Analysis}

Data were subjected to one-way analysis of variance (ANOVA) and treatment mean were compared to positive and negative control by using Tukey-Kramer Multiple Comparisons Test, a component of graph pad Instat3 Software (2000) version 3.05 by graphpad In.

\section{Results and Discussion}

\section{Acute toxicity study of the plant extract}

In acute toxicity study carried out in albino rats, the limit test at dose level of 13 and 10 $\mathrm{mg} / \mathrm{kg}$ body weight in single oral administration of phenol and petroleum spirit extract respectively did not cause any death after $72 \mathrm{~h}$ post-treatment in males and females albino rats. Also any behavioral changes including changes in skin and fur, eyes, mucus convulsion, salivation, diarrhea and lethargy did not observed in treated groups 14 days post-treatment. 


\section{Sub-chronic toxicity study}

Although $C$. procera has been reported to possess various medicinal properties and toxic effects, this work Investigates the sub-chronic toxicity of petroleum spirit extract of $C$. procera root on albino rats for four weeks (4 weeks). Clinical signs observed were common to all animals in test and control groups as reported by Jato et al., (2009); unless the increase in weight noticed in these groups. Table 5 and 6 showed results of the effects of the petroleum spirit extract $C$. procera root on liver and kidney biochemical parameters for tests (Grp II, III, \& IV) administered with $5 \mathrm{mg} / \mathrm{kg}, 10 \mathrm{mg} / \mathrm{kg}$ and $20 \mathrm{mg} / \mathrm{kg}$ respectively. At $5 \mathrm{mg} / \mathrm{kg}$ the liver biochemical parameters were not elevated statistically. This shows less toxic effects of the extract at the administered dos. On the other hand, increase in the dose to $10 \mathrm{mg} / \mathrm{kg}$ body weight.

However, group III shows the biochemical parameters when the dose was increase to $10 \mathrm{mg} / \mathrm{kg}$. The increase in ALT alone indicates toxicity as reported by Khan et al., (2001). Increased levels of serum ALT, AST, ALP, total and direct bilirubin in plasma has been reported to be sensitive indicator in liver injury. This may be due to leakage induces by membrane lipid peroxidation. Increase in the dose to $20 \mathrm{mg} / \mathrm{kg}$ produces a pronounced significant increase in ALT, AST and T. BIl, decrease in ALB. These dose dependent increases in liver biochemical parameters reveal the toxicity property due to the extract. Because ALT and AST are cytoplasmic in location and get releases in serum; an increase in the level of ALT, AST and ALP is conventionally an indicator of liver injury (Chavda et al., 2010). Albumin is the major serum protein in normal individuals. It maintains the plasma colloidal osmotic pressure, binds and solubilizes many compounds such as calcium and bilirubin.
Elevated serum albumin levels are usually the results of dehydration. Hypoalbunemia is very common in many diseases including malabsorption, liver disease, kidney diseases, severe burns, infections, cancer and some genetic abnormalities (Doumas et al., 1971).

The result of the kidney biochemical parameters indicated statistically elevated level of blood urea nitrogen as a result of the extract in the dose dependent manner. Thus, indicated reduced kidney function from 60 to 75\% (Wallace, 2007).

Table 1 and 2 shows the Serum liver Enzyme activities of (ALT, AST, and ALP) and concentrations of albumin (ALB), Total Bilirubin (T. BIL), and Direct Bilirubin (D. BIL) for groups of rats orally administered with phenol and petroleum spirit root extract of $C$. procera and livolin at 10 and 20 days respectively, Serum levels of kidney function indices of $\mathrm{ccl}_{4}$ Hepatotoxicity rats treated with the extract for 10 and 20 days are presented in table 3 and 4 respectively, while table 5 and 6 show the results of sub- chronic toxicity studies for group or rats treated with Petroleum spirit root extract.

In this study work, $\mathrm{ccl}_{4}$ induced toxicity in group II rats by clearly elevating the liver function indices, serum activities of AST, ALT, ALP, Total and Direct Bilirubin as compared with positive control (group I). The increased serum level of the enzymes may be due to cellular leakage (Alhassan et al., 2009). In $\mathrm{ccl}_{4}$ induced toxicity, $\mathrm{Ccl}_{3}{ }^{\circ}$ is produced as a free radical. It binds to lipoprotein leading to peroxidation of lipid of endoplasmic reticulum. The fact that ALT is raised at both 10 and 20 exposure indicates that $\mathrm{ccl}_{4}$ have induced toxicity in accordance with Alhassan et al., 2009 who reported that rats treated with high dose of $\mathrm{ccl}_{4}$ developed profound hepatic damage and oxidative stress as evidenced by increase in the serum 
activities of ALT, AST, ALP, Total and Direct Bilirubin that are indicators of cellular leakage and loss of functional integrity of cell membrane in liver.

Daily oral administration of $13 \mathrm{mg} / \mathrm{kg}$ phenol root extract of $C$. procera (PRECP) produces statistically significant decrease in serum ALB. Hypoalbuminaemia is very common in many diseases including liver disease and kidney diseases. The significant decrease in serum albumin here may be due to liver disease induced by $\mathrm{ccl}_{4}$ (Alhassan et al., 2009). ALT is considered a more specific and sensitive indicator of hepatocellular injury than AST in rats and dogs (Clementine et al., 2010). The amount of ALT increase is usually greater than that of AST when both are increased due to hepatic injury, in part because of the longer half-life of ALT and its higher in liver compared to other tissues and the greater proportion of AST that is bound to mitochondria (Uba et al., 2017). Hepatic dysfunction associated with increased serum ALT activity, with or without increased AST activity, includes hepatocellular necrosis, injury, or regenerative/reparative activity (Clementine et al., 2010). This also leads to significant increase in T. Bilirubin and D. Bil. As a result of destruction of heamoglobin and obstruction of bile duct respectively (Clementine et al., 2010). Therefore, the increased ALT and T. Bilirubin after 20 days exposure also indicates toxicity either due to long term exposure. On the other hand, daily oral administration of $10 \mathrm{mg} / \mathrm{kg}$ of petroleum spirit root extracts of $C$. procera for 10 and 20 days bring back the activities of liver enzymes to normal, except for Total biliuribin which significantly rise at both exposures. This increase might be due to pre-hepatic (increased production), hepatic (liver problems), or post-hepatic (bile duct obstruction), Increased total Bilirubin may lead to jaundice and can signal a number of problems (Nyblom, et al., 2006). The insignificant change in all the liver biochemical indices at 10 days indicates the hepatocurative as well as regenerative property of this extract. This may be attributed to the antioxidant properties of the photochemical presence in the extract (Zhang et al., 2015). However, the chemical constituent responsible for the pharmacological activities remains to be investigated (Mossa et al., 1991). The 10 days Histopathological analysis of the liver Plate 4, shows a mild cytolysis, with improvement in the architecture of the liver when compared with that of the control liver (plate 1) (Ovwiora, 2002) (Fig. 1).

However, kidney parameters values when compared with normal control (Grp I) and toxicant group (Grp II) shows significant increase in Urea, creatinine and potassium. This may be due to proper utilization of protein by the liver which indicates the effectiveness of the extract against kidney. At 20 days however urea and bicarbonate decrease significantly, decrease in serum urea level is associated with severely reduced liver function as reported by Ansley et al., (1993) that; in patient with a severely reduced liver function, a true intolerance of ammonia was seen and thus neurological signs after a heavy protein meal or substantially reduced urea levels may be seen. As reported by Santosh and Yamini (2010) plasma level of creatinine is independent of protein ingestion, water intake, rate of urine production and exercise. Therefore the insignificant change in electrolyte and creatinine improve the kidney state.

However, the kidney function index of Phenol root extracts indicates significant depletion of urea, creatinine and electrolyte which increase with increased day of exposure. This indicates over production of creatinine, hypernatremia, hyperkalemia and metabolic alkalosis and respiratory acidosis due to kidney 
impairment. Creatinine is removed from plasma by glomerullar filtration and excreted into urine. Increase in creatinine values is an indication of renal dysfunction (Gowda et al., 2010), this damage could be due to the accumulation of active principles of the plant extract into the kidney, accumulation of hazards can be toxic to the tubular epithelial cells (Gowda et al., 2010). Although creatinine is more specific to determine kidney injuries, our results could not confirm any harmful effects to these organs by the extracts. Gowda et al., 2010 reported that Potassium is the principle cation of the intracellular fluid and important constituent of extracelluar fluid due to its influence on muscle activity. The hyperkalemia here is associated with renal failure, although other factors such as dehydration shock or adrenal insufficiency may leads to hyperkalemia (Gowda et al., 2010).

Table.1 Serum activities of ALT, AST and ALP, and concentration of ALB, T. BIL and D. BIL for groups of ccl4 induced hepatotoxicity rats orally administered with solvents Extract of $C$. procera root and livolin for 10 days

\begin{tabular}{|l|l|l|l|l|l|l|}
\hline GROUP & $\begin{array}{l}\text { ALT } \\
(I U / L)\end{array}$ & $\begin{array}{l}\text { AST } \\
(\mathbf{I U} / \mathbf{L})\end{array}$ & $\begin{array}{l}\text { ALP } \\
(\mathbf{I U} / \mathbf{L})\end{array}$ & $\begin{array}{l}\text { ALB } \\
(\mathbf{m g} / \mathbf{d l})\end{array}$ & $\begin{array}{l}\text { T.BIL } \\
(\mathbf{m g} / \mathbf{d l})\end{array}$ & $\begin{array}{l}\text { D.BIL } \\
(\mathbf{m g} / \mathbf{d l})\end{array}$ \\
\hline I(control) & $32 \pm 4.5$ & $44.6 \pm 5.08$ & $92 . \pm 6.44$ & $4.26 \pm 0.24$ & $1.37 \pm 0.17$ & $4.0 \pm 0.3$ \\
\hline II(Livolin) & $40 \pm 4.1^{\mathrm{a}}$ & $64.7 \pm 8.6^{\mathrm{b}}$ & $281 \pm 22.5^{\mathrm{a}}$ & $1.78 \pm 0.25^{\mathrm{a}}$ & $1.8 \pm 0.09^{\mathrm{b}}$ & $8.0 \pm 0.27^{\mathrm{b}}$ \\
\hline III & $35 \pm 2.5$ & $44.6 \pm 6.77$ & $99.8 \pm 2.168$ & $2.9 \pm 0.122^{\mathrm{a}}$ & $1.39 \pm 0.25$ & $2.1 \pm 0.2$ \\
\hline IV & $33 \pm 0.577$ & $46 \pm 4.19$ & $95.2 \pm 2.78$ & $3.78 \pm 0.259$ & $1.02 \pm 0.06^{\mathrm{c}}$ & $4.43 \pm 1.0$ \\
\hline V & $39 \pm 1.00^{\mathrm{b}}$ & $51 \pm 9.62$ & $110 \pm 10.0$ & $3.34 \pm 0.51^{\mathrm{a}}$ & $1.28 \pm 0.2$ & $6.1 \pm 1.4$ \\
\hline VI & $34 \pm 1.00$ & $48.4 \pm 6.54$ & $75.4 \pm 3.286$ & $3.0 \pm 0.200^{\mathrm{a}}$ & $1.17 \pm 0.05$ & $5.8 \pm 1.7$ \\
\hline VII & $36 \pm 1.00$ & $49.2 \pm 5.2$ & $110 \pm 6.124$ & $2.9 \pm 0.123^{\mathrm{a}}$ & $1.2 \pm 0.08$ & $6.43 \pm 0.4$ \\
\hline
\end{tabular}

Values in the same column with (a), (b) and (c) are significance at $\mathrm{P}<0.001, \mathrm{P}<0.01$ and $\mathrm{P}<0.05$ respectively when compared with the control.

Table.2 Serum activities of ALT, AST and ALP, and concentrations of ALB, T. BIL and D.BIL for groups of ccl4 induced hepatotoxicity rats orally administered with solvents extract of $C$. procera root and livolin for 20 days

\begin{tabular}{|l|l|l|l|l|l|l|}
\hline GROUP & $\begin{array}{l}\text { ALT } \\
(\mathbf{I U} / \mathbf{L})\end{array}$ & $\begin{array}{l}\text { AST } \\
(\mathbf{I U} / \mathbf{L})\end{array}$ & $\begin{array}{l}\text { ALP } \\
(\mathbf{I U} / \mathbf{L})\end{array}$ & $\begin{array}{l}\text { ALB } \\
(\mathbf{m g} / \mathbf{d l})\end{array}$ & $\begin{array}{l}\text { T.BIL } \\
(\mathbf{m g} / \mathbf{d l})\end{array}$ & $\begin{array}{l}\text { D.BIL } \\
(\mathbf{m g} / \mathbf{d l})\end{array}$ \\
\hline I & $23.8 \pm 9.58$ & $43.6 \pm 3.286$ & $89.4 \pm 4.535$ & $3.5 \pm 0.08$ & $0.9 \pm 0.20$ & $0.85 \pm 0.1$ \\
\hline II & $45.6 \pm 4.67^{\mathrm{a}}$ & $59.4 \pm 9.43^{\mathrm{b}}$ & $270 \pm 21.335^{\mathrm{a}}$ & $1.3 \pm 0.2^{\mathrm{a}}$ & $1.43 \pm 0.05^{\mathrm{b}}$ & $2.2 \pm 0.4^{\mathrm{a}}$ \\
\hline III & $20.8 \pm 5.891$ & $40.6 \pm 5.595$ & $95.6 \pm 3.130$ & $2.2 \pm 0.5$ & $1.118 \pm 0.08$ & $1.03 \pm 0.2$ \\
\hline IV & $24.0 \pm 3.00^{\mathrm{c}}$ & $40 \pm 4.899$ & $92.2 \pm 2.168$ & $3.4 \pm 0.205$ & $1.58 \pm 0.18^{\mathrm{b}}$ & $0.8 \pm 0.05$ \\
\hline V & $28.8 \pm 5.933$ & $37.6 \pm 2.510$ & $86.6 \pm 3.362$ & $3.8 \pm 0.78$ & $1.1 \pm 0.07$ & $0.8 \pm 0.08$ \\
\hline VI & $27.6 \pm 2.51^{\mathrm{c}}$ & $42.8 \pm 5.630$ & $70.4 \pm 4.278^{\mathrm{b}}$ & $2.3 \pm 0.02$ & $1.6 \pm 0.52^{\mathrm{a}}$ & $0.8 \pm 0.20$ \\
\hline VII & $32 \pm 6.819^{\mathrm{c}}$ & $26 \pm 4.183^{\mathrm{a}}$ & $96 \pm 2.449$ & $2.39 \pm 0.013$ & $1.5 \pm 0.17^{\mathrm{b}}$ & $0.8 \pm 0.05$ \\
\hline
\end{tabular}

Values in the same column with (a), (b) and (c) are significance at $\mathrm{P}<0.001, \mathrm{P}<0.01$ and $\mathrm{P}<0.05$ respectively, when compared with the control. Results are expressed as mean \pm standard deviation. 
Table.3 Concentration of urea, creatinine, bicarbonate, chloride, potassium and sodium for group of CCL4 induced hepatotoxicity rats orally administered with some solvent extracts of C. proceraroot and livolin for 10 days

\begin{tabular}{|c|c|c|c|c|c|c|}
\hline GROUP & $\begin{array}{l}\text { UREA } \\
\text { (mg/dl) }\end{array}$ & $\begin{array}{l}\text { CREAT } \\
\text { (mg/dl) }\end{array}$ & $\begin{array}{l}\mathrm{HCO}_{3}{ }^{-} \\
(\mathrm{mmol} / \mathrm{l})\end{array}$ & $\begin{array}{l}\mathrm{Cl}^{-} \\
(\mathrm{mmol} / \mathrm{l})\end{array}$ & $\begin{array}{l}\mathrm{K}^{+} \\
(\mathbf{m e q} / \mathbf{l})\end{array}$ & $\begin{array}{l}\mathrm{Na}^{+} \\
(\mathrm{mmol} / \mathrm{l})\end{array}$ \\
\hline I & $\begin{array}{l}0.77 \\
\pm \\
0.1\end{array}$ & $\begin{array}{l}24.1 \\
\pm \\
4.9\end{array}$ & $\begin{array}{l}31.2 \\
\pm \\
0.9\end{array}$ & $\begin{array}{l}276 \\
\pm \\
43\end{array}$ & $\begin{array}{l}5.1 \\
\pm \\
1.1\end{array}$ & $\begin{array}{l}315.6 \\
\pm \\
41.2\end{array}$ \\
\hline II & $\begin{array}{l}0.58 \\
\pm \\
0.04\end{array}$ & $\begin{array}{l}14.3 \\
\pm \\
3.4\end{array}$ & $\begin{array}{l}66.9 \\
\pm \\
5.1^{\text {a }}\end{array}$ & $\begin{array}{l}209 \\
\pm \\
37.9^{b}\end{array}$ & $\begin{array}{l}10.1 \\
\pm \\
0.7^{\mathrm{a}}\end{array}$ & $\begin{array}{l}278.0 \\
\pm \\
41.8\end{array}$ \\
\hline III & $\begin{array}{l}0.9 \\
\pm \\
0.3^{\mathrm{a}}\end{array}$ & $\begin{array}{l}30.4 \\
\pm \\
0.2\end{array}$ & $\begin{array}{l}33.4 \\
\pm \\
0.9\end{array}$ & $\begin{array}{l}173 \\
\pm \\
3.6^{\mathrm{a}}\end{array}$ & $\begin{array}{l}5.8 \\
\pm \\
0.2\end{array}$ & $\begin{array}{l}200.7 \\
\pm \\
3.4^{\mathrm{a}}\end{array}$ \\
\hline IV & $\begin{array}{l}0.79 \\
\pm \\
0.2^{\mathrm{a}}\end{array}$ & $\begin{array}{l}33 \\
\pm \\
6.1^{c}\end{array}$ & $\begin{array}{l}34 \\
\pm \\
0.5\end{array}$ & $\begin{array}{l}149.3 \\
\pm \\
13.3^{\mathrm{a}}\end{array}$ & $\begin{array}{l}7.5 \\
\pm \\
1.8^{\mathrm{c}}\end{array}$ & $\begin{array}{l}175.9 \\
\pm \\
15.1^{\mathrm{a}}\end{array}$ \\
\hline V & $\begin{array}{l}0.7 \\
\pm \\
0.1^{\mathrm{c}}\end{array}$ & $\begin{array}{l}33.4 \\
\pm \\
2.5^{\mathrm{c}}\end{array}$ & $\begin{array}{l}43 \\
\pm \\
6.2\end{array}$ & $\begin{array}{l}177.8 \\
\pm \\
6.5^{\mathrm{a}}\end{array}$ & $\begin{array}{l}4.7 \\
\pm \\
1.8\end{array}$ & $\begin{array}{l}214.7 \\
\pm \\
6.7^{a}\end{array}$ \\
\hline VI & $\begin{array}{l}0.6 \\
\pm \\
0.2\end{array}$ & $\begin{array}{l}30.0 \\
\pm \\
3.8\end{array}$ & $\begin{array}{l}41.3 \\
\pm \\
4.5\end{array}$ & $\begin{array}{l}167.7 \\
\pm \\
0.16^{\mathrm{a}}\end{array}$ & $\begin{array}{l}6.9 \\
\pm \\
2.2^{\mathrm{c}}\end{array}$ & $\begin{array}{l}202.1 \\
\pm \\
4.4^{\mathrm{a}}\end{array}$ \\
\hline VII & $\begin{array}{l}0.63 \\
\pm \\
0.2^{\mathrm{a}}\end{array}$ & $\begin{array}{l}28.9 \\
\pm \\
2.6\end{array}$ & $\begin{array}{l}48.2 \\
\pm \\
14.5^{\mathrm{b}}\end{array}$ & $\begin{array}{l}173.9 \\
\pm \\
1.7^{\mathrm{a}}\end{array}$ & $\begin{array}{l}7.3 \\
\pm \\
2.4\end{array}$ & $\begin{array}{l}210.2 \\
\pm \\
16.9^{\mathrm{a}}\end{array}$ \\
\hline
\end{tabular}

Values in the same column with $\left({ }^{\mathrm{a}}\right),\left({ }^{\mathrm{b}}\right)$ and $\left({ }^{\mathrm{c}}\right)$ are significance at $\mathrm{P}<0.001, \mathrm{P}<0.01$ and $\mathrm{P}<0.05$ respectively compared to control group in the same column. $\mathrm{N}=5$; Results are expressed as mean \pm standard deviation. 
Table.4 Concentration of urea, creatinine, bicarbonate, chloride, potassium and sodium for group of $\mathrm{CCl} 4$ induced hepatotoxicity rats orally administered with extracts of $C$. procera root and livolin for 20 days

\begin{tabular}{|c|c|c|c|c|c|c|}
\hline GROUP & $\begin{array}{l}\text { UREA } \\
(\mathrm{mg} / \mathrm{dl})\end{array}$ & $\begin{array}{l}\text { CREAT } \\
(\mathrm{mg} / \mathrm{dl})\end{array}$ & $\begin{array}{l}\mathrm{HCO}_{3}^{-} \\
(\mathrm{mmol} / \mathrm{]}\end{array}$ & $\begin{array}{l}\mathrm{Cl}^{-} \\
(\mathrm{mmol} / \mathrm{l})\end{array}$ & $\begin{array}{l}\mathrm{K}^{+} \\
\text {(meq/L }\end{array}$ & $\begin{array}{l}\mathrm{Na}^{\mathrm{I}} \\
(\mathrm{mmol} / \mathrm{l})\end{array}$ \\
\hline I & $\begin{array}{l}1.7 \\
\pm \\
0.08\end{array}$ & $\begin{array}{l}17.97 \\
\pm \\
1.8\end{array}$ & $\begin{array}{l}18.9 \\
\pm \\
1.3\end{array}$ & $\begin{array}{l}144.2 \\
\pm \\
13.7\end{array}$ & $\begin{array}{l}2.40 \\
\pm \\
0.57\end{array}$ & $\begin{array}{l}164.3 \\
\pm \\
12.7\end{array}$ \\
\hline II & $\begin{array}{l}1.86 \\
\pm \\
0.2\end{array}$ & $\begin{array}{l}25.6 \\
\pm \\
1.99^{a}\end{array}$ & $\begin{array}{l}30.3 \\
\pm \\
0.68^{a}\end{array}$ & $\begin{array}{l}162.2 \\
\pm \\
6.7\end{array}$ & $\begin{array}{l}5.30 \\
\pm \\
0.60^{c}\end{array}$ & $\begin{array}{l}188.8 \\
\pm \\
6.93\end{array}$ \\
\hline III & $\begin{array}{l}0.87 \\
\pm \\
0.2^{\mathrm{a}}\end{array}$ & $\begin{array}{l}32.6 \\
\pm \\
3.14^{\mathrm{a}}\end{array}$ & $\begin{array}{l}29.1 \\
\pm \\
1.08^{\mathrm{a}}\end{array}$ & $\begin{array}{l}106.7 \\
\pm \\
3.2\end{array}$ & $\begin{array}{l}4.40 \\
\pm \\
0.58\end{array}$ & $\begin{array}{l}132.6 \\
\pm \\
5.01\end{array}$ \\
\hline IV & $\begin{array}{l}0.27 \\
\pm \\
0.05^{\mathrm{a}}\end{array}$ & $\begin{array}{l}18.7 \\
\pm \\
3.1\end{array}$ & $\begin{array}{l}31.7 \\
\pm \\
1.27^{\mathrm{a}}\end{array}$ & $\begin{array}{l}84.0 \\
\pm \\
21.98\end{array}$ & $\begin{array}{l}4.17 \\
\pm \\
1.04\end{array}$ & $\begin{array}{l}116.7 \\
\pm \\
18.9\end{array}$ \\
\hline $\mathrm{V}$ & $\begin{array}{l}1.33 \\
\pm \\
0.12^{\mathrm{c}}\end{array}$ & $\begin{array}{l}24.0 \\
\pm \\
1.8\end{array}$ & $\begin{array}{l}31.6 \\
\pm \\
1.3^{\mathrm{a}}\end{array}$ & $\begin{array}{l}90.2 \\
\pm \\
5.8\end{array}$ & $\begin{array}{l}3.00 \\
\pm \\
1.13\end{array}$ & $\begin{array}{l}116.7 \\
\pm \\
7.8\end{array}$ \\
\hline VI & $\begin{array}{l}1.5 \\
\pm \\
0.24\end{array}$ & $\begin{array}{l}33.6 \\
\pm \\
2.6^{\mathrm{a}}\end{array}$ & $\begin{array}{l}26.5 \\
\pm \\
1.1^{\mathrm{a}}\end{array}$ & $\begin{array}{l}152 . \\
\pm \\
33.8\end{array}$ & $\begin{array}{l}36.1 \\
\pm \\
1.33\end{array}$ & $\begin{array}{l}184.0 \\
\pm \\
32.8\end{array}$ \\
\hline VII & $\begin{array}{l}0.75 \\
\pm \\
0.10^{a}\end{array}$ & $\begin{array}{l}24.1 \\
\pm \\
1.3^{\mathrm{c}}\end{array}$ & $\begin{array}{l}39.4 \\
\pm \\
0.8^{a}\end{array}$ & $\begin{array}{l}214.5 \\
\pm \\
18.9\end{array}$ & $\begin{array}{l}3.50 \\
\pm \\
1.40\end{array}$ & $\begin{array}{l}235.9 \\
\pm \\
105.8\end{array}$ \\
\hline
\end{tabular}

Values in the same column with (a), (b) and (c) are significance at $\mathrm{P}<0.001, \mathrm{P}<0.01$ and $\mathrm{P}<0.05$ respectively, when compared with the control.Results are express as mean \pm standard deviation 
Table.5 The effect of 4 weeks sub-chronic studies of petroleum spirit $C$. procera root extract on Liver function indices of albino rats

\begin{tabular}{|c|c|c|c|c|c|c|}
\hline GRP & $\begin{array}{l}\text { ALT } \\
\text { (IU/L) }\end{array}$ & $\begin{array}{l}\text { AST } \\
\text { (IU/L) }\end{array}$ & $\begin{array}{l}\text { ALP } \\
(\text { IU/L) }\end{array}$ & $\begin{array}{l}\text { ALB } \\
\text { (mg/dl) }\end{array}$ & $\begin{array}{l}\text { T. BIL } \\
\text { (mg/dl) }\end{array}$ & $\begin{array}{l}\text { D. BIL } \\
\text { (mg/dl) }\end{array}$ \\
\hline I(control) & $\begin{array}{l}36.6 \\
\pm \\
4.45\end{array}$ & $\begin{array}{l}43.8 \\
\pm \\
4.44\end{array}$ & $\begin{array}{l}109.2 \\
\pm \\
2.588\end{array}$ & $\begin{array}{l}4.34 \\
\pm \\
0.55\end{array}$ & $\begin{array}{l}1.03 \\
\pm \\
0.202\end{array}$ & $\begin{array}{l}0.89 \\
\pm \\
0.114\end{array}$ \\
\hline II $5 \mathrm{mg} / \mathrm{kg}$ & $\begin{array}{l}26.0 \\
\pm \\
3.606\end{array}$ & $\begin{array}{l}39.8 \\
\pm \\
7.05\end{array}$ & $\begin{array}{l}116 . \\
\pm \\
1.41\end{array}$ & $\begin{array}{l}4.48 \\
\pm \\
0.54\end{array}$ & $\begin{array}{l}1.63 \\
\pm \\
0.167^{\mathrm{a}}\end{array}$ & $\begin{array}{l}0.854 \\
\pm \\
0.05899\end{array}$ \\
\hline III $15 \mathrm{mg} / \mathrm{kg}$ & $\begin{array}{l}44.6 \\
\pm \\
5.55^{c}\end{array}$ & $\begin{array}{l}47.8 \\
\pm \\
6.458\end{array}$ & $\begin{array}{l}116.4 \\
\pm \\
0.8944\end{array}$ & $\begin{array}{l}3.5 \\
\pm \\
0.509\end{array}$ & $\begin{array}{l}1.9 \\
\pm \\
0.07^{\mathrm{a}}\end{array}$ & $\begin{array}{l}1.096 \\
\pm \\
0.07797\end{array}$ \\
\hline $\begin{array}{l}\text { IV } \\
20 \mathrm{mg} / \mathrm{kg}\end{array}$ & $\begin{array}{l}61.2 \\
\pm \\
3.63^{\mathrm{a}}\end{array}$ & $\begin{array}{l}68.4 \\
\pm \\
5.81^{\mathrm{a}}\end{array}$ & $\begin{array}{l}104.6 \\
\pm \\
9.182\end{array}$ & $\begin{array}{l}3.42 \\
\pm \\
0.311^{\mathrm{c}}\end{array}$ & $\begin{array}{l}1.996 \\
\pm \\
0.1195^{\mathrm{a}}\end{array}$ & $\begin{array}{l}1.502 \\
\pm \\
0.4388^{b}\end{array}$ \\
\hline
\end{tabular}

Values with astrick $\left({ }^{\mathrm{a}}\right),\left({ }^{\mathrm{b}}\right)$ and $\left({ }^{\mathrm{c}}\right)$ are significance at $\mathrm{P}<0.001, \mathrm{P}<0.01$ and $\mathrm{P}<0.05$ respectively compared to control group in the same column. Results are expressed as mean \pm standard deviation

Table.6 Effects of 4 weeks sub-chronic studies of petroleum spirit $C$. procea root extract on the kidney function indices of albino rats

\begin{tabular}{|c|c|c|c|c|c|c|}
\hline Group & $\begin{array}{l}\text { UREA } \\
\text { (mg/dl) }\end{array}$ & $\begin{array}{l}\text { CREAT } \\
\text { (mg/dl) }\end{array}$ & $\begin{array}{l}\mathrm{HCO}_{3}{ }^{-} \\
(\mathrm{mmol} / \mathrm{l})\end{array}$ & $\begin{array}{l}\mathrm{Cl}^{-} \\
(\mathrm{mmol} / /\end{array}$ & $\begin{array}{l}\mathrm{K}^{+} \\
\text {(meq/l) }\end{array}$ & $\begin{array}{l}\mathrm{Na}^{+} \\
(\mathrm{mmol} / \mathrm{l})\end{array}$ \\
\hline I(control) & $\begin{array}{l}1.004 \\
\pm \\
0.2138\end{array}$ & $\begin{array}{l}35.24 \\
\pm \\
6.004\end{array}$ & $\begin{array}{l}27.28 \\
\pm \\
3.759\end{array}$ & $\begin{array}{l}232.2 \\
\pm \\
29.736\end{array}$ & $\begin{array}{l}2.542 \\
\pm \\
0.7084\end{array}$ & $\begin{array}{l}249.38 \\
\pm \\
27.938\end{array}$ \\
\hline II 5mg/kg & $\begin{array}{l}0.7512 \\
\pm \\
0.06\end{array}$ & $\begin{array}{l}30.78 \\
\pm \\
1.06\end{array}$ & $\begin{array}{l}24.00 \\
\pm \\
0.66\end{array}$ & $\begin{array}{l}418.9 \\
\pm \\
115.26^{c}\end{array}$ & $\begin{array}{l}2.94 \\
\pm \\
0.151\end{array}$ & $\begin{array}{l}449.54 \\
\pm \\
130.08^{c}\end{array}$ \\
\hline III 15mg/kg & $\begin{array}{l}0.804 \\
\pm \\
0.1009\end{array}$ & $\begin{array}{l}34.72 \\
\pm \\
8.228\end{array}$ & $\begin{array}{l}31.7 \\
\pm \\
7.342\end{array}$ & $\begin{array}{l}200.96 \\
\pm \\
115.94\end{array}$ & $\begin{array}{l}3.480 \\
\pm \\
0.3421^{b}\end{array}$ & $\begin{array}{l}229.28 \\
\pm \\
116.55\end{array}$ \\
\hline IV $20 \mathrm{mg} / \mathrm{kg}$ & $\begin{array}{l}0.608 \\
\pm \\
0.11^{\mathrm{a}}\end{array}$ & $\begin{array}{l}33.72 \\
\pm \\
5.84\end{array}$ & $\begin{array}{l}31.18 \\
\pm \\
1.84\end{array}$ & $\begin{array}{l}433.6 \\
\pm \\
69.60^{\mathrm{b}}\end{array}$ & $\begin{array}{l}3.9 \\
\pm \\
0.071^{\mathrm{a}}\end{array}$ & $\begin{array}{l}481.26 \\
\pm \\
86.95^{b}\end{array}$ \\
\hline
\end{tabular}

Values in the same column with the same letter $\left({ }^{\mathrm{a}, \mathrm{b}}{ }^{\mathrm{and}}{ }^{\mathrm{c}}\right.$ ) are significance at $\mathrm{P}<0.001, \mathrm{P}<0.01$ and $\mathrm{P}<0.05$ respectively. Results are expressed as mean \pm standard deviation 
Fig.1
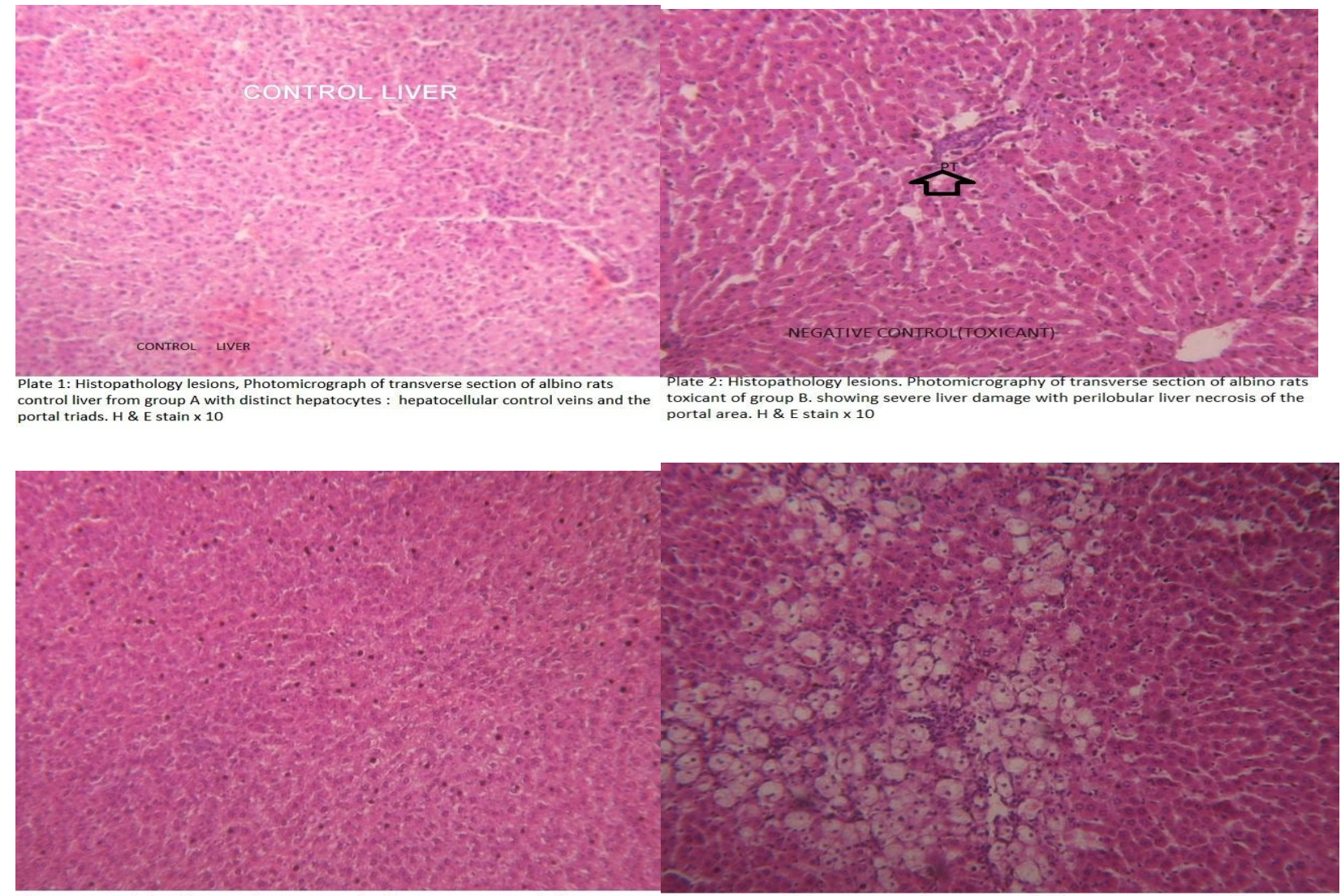

Plate 4:Histopathology lesions, photomicrography of transverse section of albino rats test Plate 7: Histopathology lesions ; Photomicrograph of transverse section of albino rats group D liver treated with petroleum spirit extract of C. Procera root, showing a mild test group $\mathrm{G}$ treated with phenolic extract of $\mathrm{C}$. Procera root, showing moderate cytolysis cytolysis. H \& E stain $x 10$ and karyolysis. $\mathrm{H} \& \mathrm{E}$ stain $\times 10$

Increased bicarbonate concentration may be due to metabolic alkalosis and respiratory acidosis which result in glomerulonepharitis, pyloric obstruction, diarrhea and diabetes mellitus (Gowda et al., 2010).

In conclusion, phenol root extract of $C$. procera causes severe liver and kidney damage, the histopathological analysis of the liver plate 4 shows the extent of the hepatocyte damage, moderate cytolysis and karyolysis with development of unusual features which needs to be studied further.

\section{Acknowledgement}

This project was fully funded by Tertiary Education Trust Fund (TETFUND), a parastatal of Federal Ministry of Education
Abuja, Nigeria under Institutions Based Research (IBR) program. The authors also acknowledged the use of laboratory facilities from Jigawa state Polytechnic Dutse Nigeria.

\section{References}

Alhassan, A. J., Sule, M. S., Hassan, J. A., Baba, B. A. and Aliyu, M. D. (2009). Ideal Hepatotoxicity model using $\mathrm{CCl}_{4}$. Bayero Journal of Pure an Applied Sciences, 2(2): 185-187.

Aliyu, B.S., (2006): Common Ethnomedicinal Plants of the Semiarid Regions of West Africa; Their Description and Phytochemicals. Triumph Publishing Company, Kano. Pp 193-198

Ansley J.D. Isaacs J.W, Rikkers L.F. (1993). Quantitative Tests of Nitrogen and 
Restoration of Nitrogen Homeostasis in a Man with Ornithine. Elsevier 42, 1336- 1339

Chavda R, Validia, K.R Gokani, R. (2010). Hepatoprotective and Antioxidant Activity of Root Bark of Calotropis procera R.Br (Asclepediacea). Int. J. Pharmacol., 6(6): 937-943.

Clementine, Y. F., and Tar Choon A.W., (2010). Liver Function Tests (LFTs) Laboratory Insights Number 1 ,Volume 19 Proceedings of Singapore Healthcare.

Dhiman RK, Chawla YK. (2005). Herbal medicines for liver diseases. Dig Dis Sci., 50(10): 1807-12. Review. Int J Mol Sci. 16(12): 28705-28745.

Emmanuel, C. Chukwuma, Mike O. Soladoye, Roseline T. Feyisola (2015) Traditional medicine and the future of medicinal Plants in Nigeria, Journal of Medicinal Plants Studies; 3(4): 23-29

Garba, U.K., Alhassan, A.J., Muntari, Bala, (2017). Hepato-Curative Effects Of Crude Methanol And Ethanol Root Extracts Of Calotropis Procera Toxicity In Albino Rats, Bayero Journal of Pure and Applied Sciences, 10(2): $134-140$

Gowda, S, Desai P.B., Kulkarni, S.S., Hull, V.V., Math, A.A.K., Vernekar, S.N., (2010). Markers of renal function tests. North Am J Med Sci., 2: 170-173.

Ming H. Sha L. Hor Yue T. Ning W. Sai-Wah T. and Yibin F. (2015). Current status of herbal medicines in chronic liver disease therapy: the biological effects, molecular targets and future prospects.

Mossa J.S., Tariq M., Mohsin A., Ageel A.M., AI-Yahya M.A., Al-Said M.S., and Rafatullah S. (1991). Pharmacological studies on aerial parts of Calotropis procera, American Journal of Chinese Medicine, Vol. XIX. Nos. 3-4, pp. 223-231

Nyblom, H., Björnsson, E., Simrén, M., Aldenborg, F., Almer, S. and Olsson, R. (2006). "The AST/ALT ratio as an indicator of cirrhosis in patients with PBC". Liver Int. 26(7): 840- 5.

Ovwioro, O.G (2002). Histochemistry and tissue pathology Principle and Technique $2^{\text {nd }}$ Edition Oxford: Clarendon Press; pp. 10-35.

Santosh N and Yamini B. T (2010). Amelioration of cisplatin induced nephorotoxicity by PTY: A herbal Preparation Elsevier 48, 2253-2258

Wallace, S.M., (2007) Isolated systolic hypertension is characterized by increased aortic stiffness and endothelial dysfunction. Hypertension 50(1): 228-33

Yu-Jie Zhang, Ren-You Gan, Sha Li, Yue Zhou, An-Na Li, Dong-Ping $\mathrm{Xu}$ and Hua-Bin Li (2015). Antioxidant Phytochemicals for the Prevention and Treatment of Chronic Diseases, Molecules, 20, 21138-21156; doi: 10.3390/molecules201219.

\section{How to cite this article:}

Zaharaddeen Shehu, Garba Uba, A.J. Alhassan and Muntari Bala. 2019. Hepato-protective Effects of Crude Phenol and Petroleum Spirit Root Extracts of Calotropis procera (Sodom of Apple) on CCL4 Induced Hepatotoxicity in Albino Rats. Int.J.Curr.Microbiol.App.Sci. 8(02): 2733-2743. doi: https://doi.org/10.20546/ijcmas.2019.802.320 